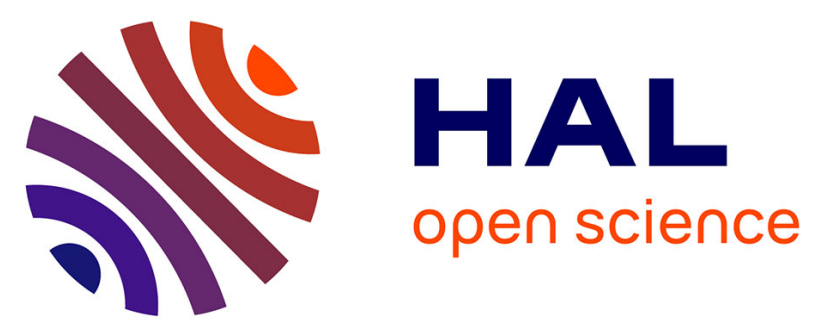

\title{
Self-assembled monolayer for AFM measurements of Tobacco Mosaic Virus (TMV) at the atomic level
} Matthieu Meillan, Michaël Ramin, Thierry Buffeteau, Sophie Marsaudon, Michaël Odorico, Shu-Wen W. Chen, Jean-Luc Pellequer, Marie Degueil, Karine Heuzé, Luc Vellutini, et al.

\section{To cite this version:}

Matthieu Meillan, Michaël Ramin, Thierry Buffeteau, Sophie Marsaudon, Michaël Odorico, et al.. Self-assembled monolayer for AFM measurements of Tobacco Mosaic Virus (TMV) at the atomic level. RSC Advances, 2014, 4 (23), pp.11927-11930. 10.1039/c3ra46716c . hal-02010365

\section{HAL Id: hal-02010365 https://hal.science/hal-02010365}

Submitted on 14 Jan 2021

HAL is a multi-disciplinary open access archive for the deposit and dissemination of scientific research documents, whether they are published or not. The documents may come from teaching and research institutions in France or abroad, or from public or private research centers.
L'archive ouverte pluridisciplinaire HAL, est destinée au dépôt et à la diffusion de documents scientifiques de niveau recherche, publiés ou non, émanant des établissements d'enseignement et de recherche français ou étrangers, des laboratoires publics ou privés. 
Cite this: RSC Adv., 2014, 4, 11927

\section{Self-assembled monolayer for AFM measurements of Tobacco Mosaic Virus (TMV) at the atomic level $\uparrow$}

Received 15th November 2013 Accepted 17th February 2014

DOI: $10.1039 / c 3 r a 46716 c$

www.rsc.org/advances

\author{
Matthieu Meillan, ${ }^{a}$ Michaël A. Ramin, ${ }^{a}$ Thierry Buffeteau, ${ }^{\text {ab }}$ Sophie Marsaudon, ${ }^{c}$ \\ Michaël Odorico, ${ }^{d}$ Shu-wen W. Chen, ${ }^{e}$ Jean-Luc Pellequer, ${ }^{d}$ Marie Degueil, ${ }^{a b}$ \\ Karine Heuzé, ${ }^{\mathrm{ab}}$ Luc Vellutini $^{\mathrm{ab}}$ and Bernard Bennetau*ab
}

Biosensors are based on the conversion of a biological response to an electrical signal. One of the major challenges is to ascertain that the receptor is not denatured when immobilised (covalently or not) on the device. In this work, a protein receptor (virus) was immobilised on two different surfaces, mica and self-assembled monolayer (SAM), and its height was determined by atomic force microscopy measurements at the atomic level. Results clearly showed that expected dimensions of Tobacco Mosaic Virus (TMV) are obtained after immobilisation onto a soft organic SAM.

Self-assembled monolayers provide a simple way to functionalise a solid surface and play a key role in the development of biotechnology such as biosensors. ${ }^{1-3}$ SAMs present a sum of qualities: chemically stable, low roughness, provide a suitable orientation of biomolecules, and maintain the structural integrity of receptors. In this work, we focused on the latter characteristic using the paradigm that if a molecule is covalently immobilised on SAM, its three-dimensional structure (3D) should be preserved as evidence by its molecular height measurement with atomic force microscopy (AFM). During the last decade, Atomic Force Microscopy (AFM) proved to be a commonly used technique for imaging in the field of biophysical research and it is clear now that AFM is much more than a high resolution microscope. ${ }^{4-7}$ Many parameters influence the quality of AFM data, in particular the characteristics of the tip, the measurement modes (contact mode, oscillating mode,

a'Univ. Bordeaux, ISM, UMR 5255, F-33400 Talence, France.E-mail: b.bennetau@ism. $u$-bordeaux.fr

${ }^{b}$ CNRS, ISM, UMR 5255, F-33400 Talence, France

'Univ. Bordeaux, CBMN, UMR 5248, F-33600 Pessac, France

${ }^{d} C E A$, iBEB, Service de Biochimie et Toxicologie Nucléaire, F-30207 Bagnols sur Cèze, France

${ }^{e} 13$ Avenue de la Mayre, F-30200 Bagnols sur Cèze, France

$\uparrow$ Electronic supplementary information (ESI) available: Synthesis of organic compounds and their characterisations (NMR spectra $\left({ }^{1} \mathrm{H}\right.$ and ${ }^{13} \mathrm{C}$ ), FTIR, SMHR-ESI). Chemical modification of the surfaces (PM-IRRAS, contact angles and AFM). See DOI: 10.1039/c3ra46716c tapping mode, etc.), the preparation of the sample and of course, the type of immobilisation (physi- or chemisorption) to which the sample is immobilised. ${ }^{8}$ For example, the measured heights of single antibody molecules, physisorbed on mica, were found around $2 \mathrm{~nm}$ whereas the expected value measured by X-rays is around $4 \mathrm{~nm}$.

To explain this experimental result, it is generally argued that biological samples may be crushed by the AFM tip during imaging or distorted by the adsorption forces of mica. It is obvious that a hard and highly charged mineral substrate (such as mica) creates difficulties during the adsorption of molecules on which they tend to partially denature. ${ }^{9}$ To overcome these drawbacks, systems for depositing molecules such as functionalised self-assembled monolayers are emerging. ${ }^{10}$

For this purpose, a new ureido silylated compound (6) was prepared in a readily accessible way (Scheme 1) via a coupling between a functional amine and an unsaturated isocyanate. ${ }^{11} \mathrm{It}$ is noteworthy that this strategy has been previously used in our previous work for the formation of vinyl-terminated monolayer. ${ }^{12}$ The amino group of the amino carboxylic acid (1) was protected by tert-butoxycarbonyl group (Boc) to afford compound (2) then the carboxylic acid group was protected by $o$ nitrobenzyl alcohol to yield compound (3). After deprotection of the amino group, the condensation of the resulting ammonium (4) with unsaturated 10-isocyanatodec-1-ene yielded to ureido compound (5). Finally, the ureido silylated compound (6) was obtained in the last step after silylation of compound (5) with trimethoxysilane with an overall yield of $60 \%$. For spectroscopic data of compounds (2)-(6), see ESI. $\dagger$

The alkoxysilane (6) was chemisorbed onto $\mathrm{SiO}_{2}$ surface (Scheme 2) in optimised conditions (see ESI $\dagger$ ) in order to obtain a homogeneous and smooth surface.

The topography of the surface was analysed by AFM measurements. The identification of the protected carboxylic acid groups-terminated monolayers onto the surface as well as the subsequent chemical surface modifications were performed using contact angles measurements and Polarisation Modulation Infrared Reflection Adsorption Spectroscopy (PM-IRRAS). 


$$
\longrightarrow \text { (1) }
$$

Scheme 1 Synthesis of ureido silylated coupling agent (6). (a) $\mathrm{Boc}_{2} \mathrm{O}$, tert-butanol- $\mathrm{H}_{2} \mathrm{O}, \mathrm{pH}$ 13, 16 h; (b) 2-nitrobenzyl alcohol, DCC, DMAP, $\mathrm{CH}_{2} \mathrm{Cl}_{2}$; (c) TFA, $\mathrm{CH}_{2} \mathrm{Cl}_{2}, 4 \mathrm{~h}$; (d) 10-isocyanatodec-1-ene, $\mathrm{Et}_{3} \mathrm{~N}$, $\mathrm{CH}_{2} \mathrm{Cl}_{2}$; (e) $\mathrm{HSi}(\mathrm{OMe})_{3}$, cat. Karstedt, $65^{\circ} \mathrm{C}, 20 \mathrm{~h}$.

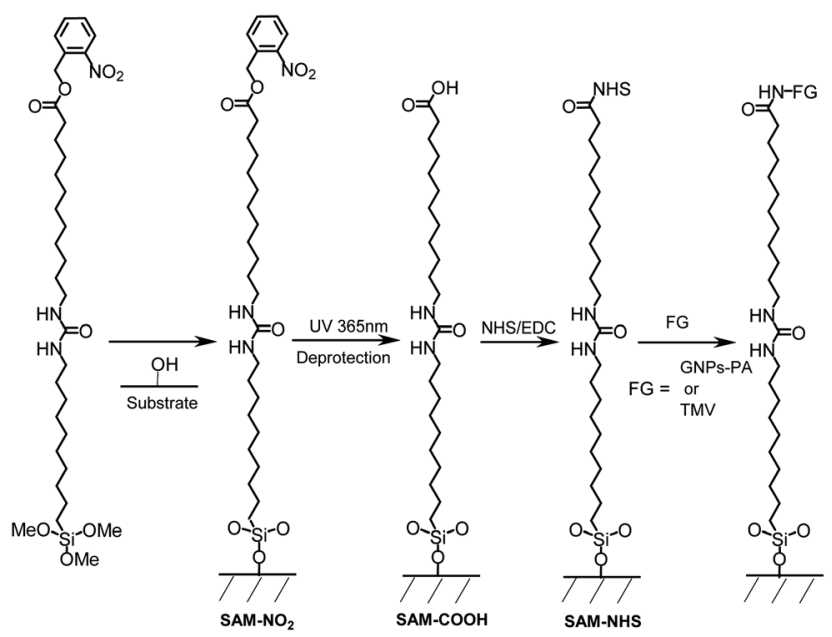

Scheme 2 Representation of the silanisation of the surface and immobilisation of GNPs-PA or TMV on SAM-COOH.

Due to its high sensitivity in surface absorption detection, PM-IRRAS has been used successfully to obtain vibrational spectra of Langmuir-Blodgett (LB) monolayers, lipid bilayers and SAMs deposited onto metal oxide substrates. ${ }^{13-16}$ In our case, we have used PM-IRRAS to monitor the chemical reactions of the terminal functions of the surface (Fig. 1). The very high sensibility of PM-IRRAS allowed us to characterise easily each step. Spectra were recorded with a very good signal-to-noise ratio, allowing each time the identification of the different functional groups of the investigated molecules (alkyl chains, urea and terminal functional groups).

Among the photolabile groups, $(o-\mathrm{NB})$ alcohol is widely used in polymer and material sciences. ${ }^{17}$ The removal of the nitrobenzyl moiety was achieved by ultraviolet light (365 nm). The successful chemical reaction was analysed by PM-IRRAS revealing the complete disappearance of the nitro band $\left(\nu_{\text {as }} \mathrm{NO}_{2}\right.$ $=1529 \mathrm{~cm}^{-1}$ ) and the appearance of a new broad band around $1707 \mathrm{~cm}^{-1}$ characteristic of acid groups as previously reported. ${ }^{18}$ For SAM-NO $\mathbf{N O}_{2}$ and SAM-COOH the methylene stretching bands are observed in similar positions at 2927 and $2855 \mathrm{~cm}^{-1}$

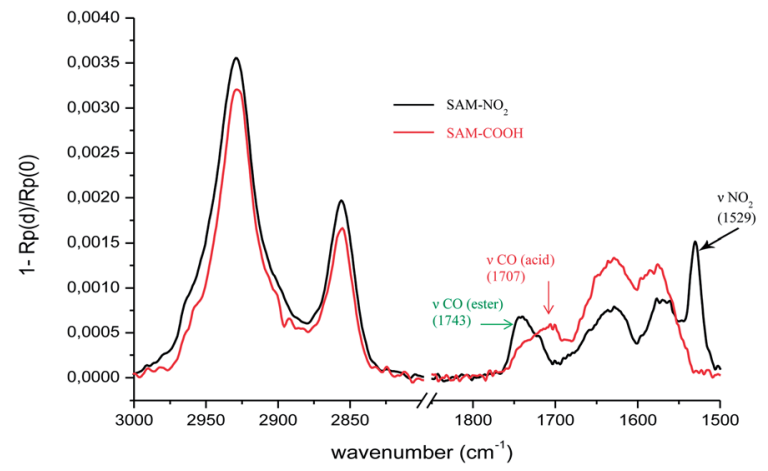

Fig. 1 PM-IRRAS spectra of SAM-NO $\mathrm{N}_{2}$ and SAM-COOH, in the 3000$2800 \mathrm{~cm}^{-1}$ and $1850-1500 \mathrm{~cm}^{-1}$ spectral ranges.

respectively for the antisymmetric $\left(\nu_{\text {as }}\left(\mathrm{CH}_{2}\right)\right)$ and symmetric $\left(\nu_{\mathrm{s}}\left(\mathrm{CH}_{2}\right)\right)$ modes. The high wavenumbers of these modes indicates that the alkyl chains were disordered in the grafted molecules whereas similar intensities do not reveal any degradation of the monolayer during the photochemical cleavage.

Average roughness of this new SAM-COOH was found (Fig. 2) similar to that of the bare substrate $\left(R_{\mathrm{q}}=0.48 \mathrm{~nm}\right.$ over $\left.25 \mu \mathrm{m}^{2}\right)$ at the difference of normally used or commercially available SAM-COOH. The roughness is a crucial parameter for measuring TMV at the atomic level by AFM. Water contact angles were found around $71^{\circ}$ for the $\mathbf{S A M}-\mathbf{N O}_{2}$ and $55^{\circ}$ for the SAM-COOH, after deprotection of the acid groups. These values are consistent with those reported in the literature, ${ }^{\mathbf{1 9 , 2 0}}$ revealing the presence of more polar groups at the surface.

Immobilisation of biomolecules onto a carboxylic acid terminated monolayer is usually achieved by activation of $\mathrm{COOH}$ groups with $N$-ethyl- $N^{\prime}$-(3-(dimethylamino)propyl)-carbodiimide- $N$-hydroxysuccinimide (EDC-NHS). The activated esters (succinimidyl esters) react with the free amino groups of biomolecules to form the amido bonds on the surface.

TMV was immobilised covalently (Scheme 2) onto a carboxylic acid-terminated self-assembled monolayer (SAMCOOH). TMV is a well-calibrated biological system, ${ }^{21,22}$ which can be immobilised on various surfaces. ${ }^{23}$ This virus is made of 2130 copies of a unique coat protein which is replicated helicoidally around its RNA, forming a cylinder about $300 \mathrm{~nm}$ in length and $18.0 \mathrm{~nm}$ diameter. ${ }^{24,25}$

In the field of biosensors technology, the reliability of sensors strongly depends on the control of the immobilisation of biomolecules on the solid substrates, ${ }^{26}$ and the activation
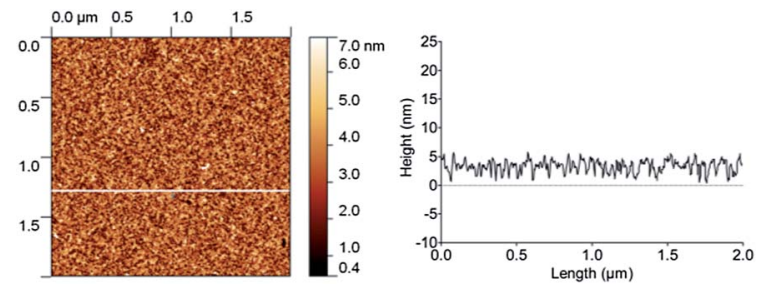

Fig. 2 AFM height image $\left(2 \times 2 \mu \mathrm{m}^{2}\right)$ in the tapping mode of SAM$\mathrm{COOH}$ (left) with a cross-section profile (right). 
step is a crucial parameter for the repeatability of measurements. A literature survey about this step shows that the relative concentrations in EDC and NHS strongly vary from a study to another one. ${ }^{27-31}$ Recently, it was shown by transmission IR spectroscopy studies that activated esters, at the surface of hydrogenated porous silicon, can be obtained with a high yield if the respective concentrations of EDC and NHS are carefully chosen. $^{32}$

In our case, transmission IR spectroscopy is not valuable because of the chemical structure of the substrate which limits the molecular information to the stretching vibrations of the alkyl chains. ${ }^{33}$ However, using the PM-IRRAS technique, we were able to monitor carefully the activation of $\mathrm{COOH}$ groups. With the ratio $[\mathrm{EDC}] /[\mathrm{NHS}]=1.2$, we observed almost complete disappearance of the band associated with acid groups $\left(1707 \mathrm{~cm}^{-1}\right)$ and the appearance of three new bands $(1816,1781$ and $1734 \mathrm{~cm}^{-1}$ ) assigned to the stretching of the carbonyl ester groups (see Fig. S2, $\uparrow$ SAM-NHS). Additional information on the molecular orientation can be obtained by comparison of the experimental PM-IRRAS spectrum with the one calculated for an isotropic orientation of the molecules. ${ }^{\mathbf{1 6}}$

In order to demonstrate the ability of the SAM-COOH to generate amide bond formation, gold nanoparticles, coated with protein A (GNPs-PA; $\varnothing \sim 20 \mathrm{~nm}$ ), were used to provide visual evidence of their attachments to the activated surface sites (Scheme 2). Successful amide bond formation was confirmed by PM-IRRAS (Fig. S3 $\dagger$ ) with the disappearance of the carbonyl bands (1816 and $1781 \mathrm{~cm}^{-1}$ ), with in parallel, an increase of the amide 1 and amide 2 bands at 1653 and 1543 $\mathrm{cm}^{-1}$ respectively, due to the amido bond formation between the carboxylic acid groups of the surface and the free amino groups of protein A.

The modified surfaces were also studied by AFM (Fig. 3). Excellent GNPs-PA dispersion was observed when the nanoparticles were used at a concentration of $\left(3.2 \mu \mathrm{g} \mathrm{mL}^{-1}\right)$. Thus, height analysis has been easily performed and the particle size was determined to be $(19.0 \pm 1.1 \mathrm{~nm} ; N=20)$ which is consistent with the expected value $(\varnothing=20.4 \pm 0.6 \mathrm{~nm}$; see ESI $\dagger)$.

It must be noted that negative control experiments, imaged in the same conditions, with no EDC-NHS activation, result in no immobilisation of GNPs-PA demonstrating that this new ureido-based SAM-COOH prevents non-specific adsorption like previously reported with poly(ethyleneglycol) PEG-based monolayers. ${ }^{34}$

Once we had confirmed that the SAM-COOH monolayer was indeed active for the covalent immobilisation of GNPs-PA, we used the SAM-COOH in the same way to bond covalently TMVs

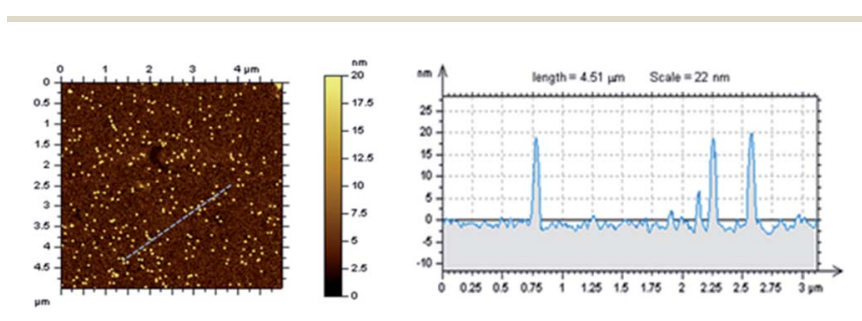

Fig. 3 Height image of GNPs-PA (left) and profile (right).
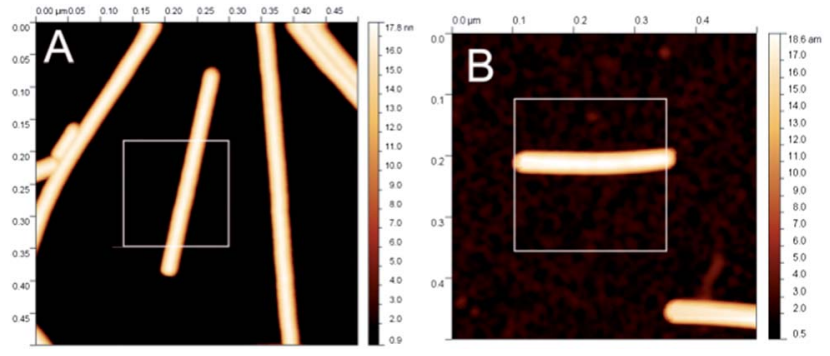

Fig. 4 Height image of isolated TMV particles using the tapping mode in air on mica (A) and on SAM (B).
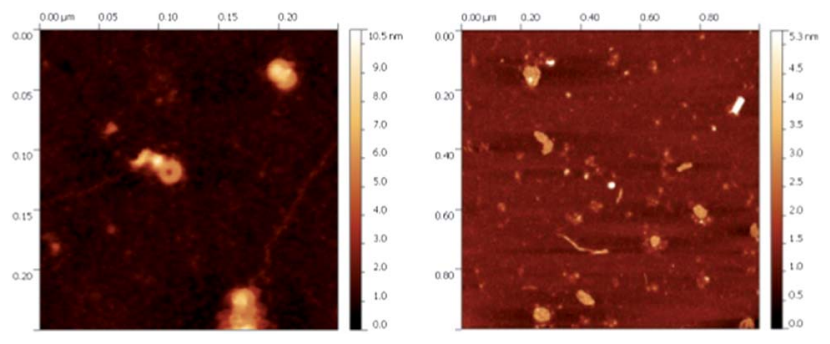

Fig. 5 AFM images of denaturated TMVs.

according to the same experimental procedure. TMV particles were imaged using AFM with the tapping mode in air in two deposition conditions: physisorbed on mica or covalently bound to SAMs (Fig. 4). AFM images when flattened using NanoScope software and further processed for removing stripe noise. $^{35}$

Height values were obtained by fitting a series of ellipsoids on single TMV particles ${ }^{36}$ using singled-out regions similar to those shown in white boxes on Fig. 4.

The average TMV height on mica was found to be $17.0 \pm$ $0.1 \mathrm{~nm}$ (ave \pm stdev, $N=802$ ) whereas it was $18.1 \pm 0.1 \mathrm{~nm}$ when the TMV was bound to SAM surface (ave $\pm \operatorname{stdev,~} N=521$ ). AFM images were obtained at the minimum imaging force. Similar measurements were repeated several times over a period of 2 years with different TMV preparations, different batches of SAMs, different cantilevers and different AFM instruments. It shows clearly that SAM surfaces allow imaging TMVs particles, without distortion. ${ }^{24}$ For comparison, AFM images of denaturated TMVs are given below.

On the left AFM image (Fig. 5; $250 \times 250 \mathrm{~nm}^{2}$ ), using the peak force mode, the presence of RNA single strands, characteristic of denatured TMV particles, can be observed. On the right image, a broken piece of TMV of about $50 \mathrm{~nm}$ length is also characteristic of denatured TMV (expected full length is about $300 \mathrm{~nm})$.

\section{Conclusions}

In summary, for biosensors as well as structural biology applications, it is critical to measure height and shape of biomolecules as accurate as possible. Here, we clearly show that the adsorption forces on mica induced a reduction in measured 
height of about $1 \mathrm{~nm}$. For the development of biosensors, keeping the original shape of the receptor is a key to sensitivity and specificity. Thus, we suggest that SAM surfaces should be preferred for the development of biosensors substrates over mineral ones.

\section{Notes and references}

1 T. Wink, S. J. van Zuilen, A. Bult and W. P. van Bennkom, Analyst, 1997, 122(4), 43R.

2 Y. Zhou, C. W. Chiu and H. Liang, Sensors, 2012, 12(11), 15036.

3 P. Massé, L. Vellutini, B. Bennetau, L. Blanc, C. Dejous, D. Rebière, P. Weisbecker and J.-P. Pillot, J. Mater. Chem., 2011, 21, 14581.

4 P. Parot, Y. F. Dufrene, P. Hinterdorfer, C. Le Grimellec, D. Navajas, J.-L. Pellequer and S. Scheuring, J. Mol. Recognit., 2007, 20, 418.

5 D. Müller and Y. Dufrêne, Nat. Nanotechnol., 2008, 3, 261.

6 P. Hinterdorfer, M. Garcia-Parajo and Y. Dufrêne, Acc. Chem. Res., 2012, 45, 327.

7 I. Casuso, F. Rico and S. Scheuring, J. Mol. Recognit., 2011, 24, 406.

8 A. Alessandrini and P. Facci, Meas. Sci. Technol., 2005, 16, R65.

9 K. Umemura, K. Sutoh, F. Tokunaga, M. Kataoka, H. Kamikubo, H. Arakawa and A. Ikai, Scanning, 1996, 18, 275.

10 Z. Lv, J. Wang, G. Chen and L. Deng, Int. J. Biol. Macromol., 2010, 47, 661.

11 H. Nam, M. Granier, B. Boury and S. Y. Park, Langmuir, 2006, 22, 7132 .

12 M. A. Ramin, G. Le Bourdon, K. Heuzé, M. Degueil, C. Belin, T. Buffeteau, B. Bennetau and L. Vellutini, Langmuir, 2012, 28, 17672 .

13 T. Buffeteau, B. Desbat and J. M. Turlet, Appl. Spectrosc., 1991, 45, 380.

14 Y. S. Shon, S. Lee, R. Colorado Jr, S. S. Perry and T. R. Lee, J. Am. Chem. Soc., 2000, 122, 7556.

15 D. M. Spori, N. V. Venkataraman, S. G. P. Tosatti, F. Durmaz, N. D. Spencer and S. Zürcher, Langmuir, 2007, 23, 8053.

16 M. A. Ramin, G. Le Bourdon, N. Daugey, B. Bennetau, L. Vellutini and T. Buffeteau, Langmuir, 2011, 27, 6076.

17 For a recent review of the use of $o$-nitrobenzyl alcohol derivatives in material science, see for example: H. Zhao,
E. S. Sterner, E. B. Coughlin and P. Theato, Macromolecules, 2012, 45, 1723.

18 H. Rahma, T. Buffeteau, C. Belin, G. Le Bourdon, M. Degueil, B. Bennetau, L. Vellutini and K. Heuzé, ACS Appl. Mater. Interfaces, 2013, 5, 6843.

19 P. F. Driscoll, E. Milkani, C. R. Lambert and W. G. Mc Gimpsey, Langmuir, 2010, 26, 3731.

20 E. Besson, A. M. Gue, J. Sudor, H. Korri-Youssoufi, N. Jaffrezic and J. Tardy, Langmuir, 2006, 22, 8346.

21 A. N. Creager, The Life of a Virus: Tobacco Mosaic Virus as an Experimental Mode, The University of Chicago Press, 2002.

22 M. H. Trinh, M. Odorico, L. Bellanger, M. Jacquemond, P. Parot and J.-L. Pellequer, J. Mol. Recognit., 2011, 24, 503.

23 A. Azimzadeh, J.-L. Pellequer and M. H. V. van Regenmortel, J. Mol. Recognit., 1992, 5, 9.

24 R. Pattanayek and G. J. Stubbs, J. Mol. Biol., 1992, 228, 516. 25 M. H. Trinh, M. Odorico, M. E. Pique, J.-M. Teulon, V. A. Roberts, L. F. Ten Eyck, E. D. Getzoff, P. Parot, S.-w. W. Chen and J.-L. Pellequer, Structure, 2012, 20, 113.

26 S. M. Borisov and O. S. Wolfbeis, Chem. Rev., 2008, 108, 423. 27 N. Patel, M. C. Davies, M. Hartshorne, R. J. Heaton, C. J. Roberts, S. B. J. Tendler and P. M. Williams, Langmuir, 1997, 13, 6485.

28 F. Wei, B. Sun, Y. Guo and X. Z. Zhao, Biosens. Bioelectron., 2003, 18, 1157.

29 L. S. Jang and H. K. Keng, Biomed. Microdevices, 2008, 10, 203.

30 L. K. Wolf, D. E. Fullenkamp and R. M. Georgiadis, J. Am. Chem. Soc., 2005, 127, 17453.

31 J. W. Lee, S. J. Sim, S. M. Cho and J. Lee, J. Biosens. Bioelectron., 2005, 20, 1422.

32 S. Sam, L. Touahir, A. J. Salvador, P. Allongue, J.-N. Chazalviel, A. C. Gouget-Laemmel, C. Henry de Villeneuve, A. Moraillon, F. Ozanam, N. Gabouze and S. Djebbar, Langmuir, 2010, 26, 809.

33 D. H. Dinh, L. Vellutini, B. Bennetau, C. Dejous, D. Rebière, E. Pascal, D. Moynet, C. Belin, B. Desbat, C. Labrugère and J.-P. Pillot, Langmuir, 2009, 25, 5526.

34 T. Böcking, K. A. Kilian, K. Gauss and J. J. Gooding, Langmuir, 2006, 22, 3494.

35 S.-w. W. Chen and J.-L. Pellequer, BMC Struct. Biol., 2011, $11,7$.

36 S.-w. W. Chen, M. Odorico, M. Meillan, L. Vellutini, J.-M. Teulon, P. Parot, B. Bennetau and J.-L. Pellequer, Nanoscale, 2013, 5, 10877. 